\title{
Restriction fragment length polymorphism of the L-myc gene is not a prognostic factor in bladder cancer patients
}

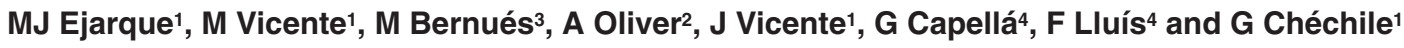 \\ 1Urology Service and 2Laboratory Service, Fundació Puigvert, Barcelona, Spain; ${ }^{3}$ nstitut de Biologia Fonamental, Universitat Autònoma de Barcelona, \\ Bellaterra, Barcelona, Spain; “Laboratori d'Investigació Gastrointestinal, Hospital de la Santa Creu i Sant Pau, Barcelona, Spain
}

Summary The L-myc restriction fragment length polymorphism has been suggested to be of prognostic significance in some types of primary tumours. We examined the prognostic and susceptibility significance of the L-myc genotype in a group of 98 bladder cancer patients. The L-myc genotype did not correlate with any pathologic parameter and does not offer any clinical utility in patients with bladder cancer.

Keywords: proto-oncogenes; restriction fragment length polymorphism; bladder cancer; prognostic factors

The restriction enzyme Eco RI identifies a two-allele system for the L-myc gene with fragment sizes of 10.0 and 6.6 kilobases and results in three possible allelotypes: homozygotic for the large allele (LL), homozygotic for the small allele (SS) or heterozygotic (LS). The prognostic significance of the L-myc allelotype of genomic DNA has been studied previously in several tumours (lung, colorectal, breast, soft tissue, leukaemia, lymphoma, stomach, kidney, oral cavity and liver). However, conficting results were reported. In this study we have investigated the L-myc genotype of 98 primary bladder cancer patients in an attempt to determine its utility as a prognostic, and as a susceptibility, factor in a Catalonian population.

\section{MATERIALS AND METHODS}

Ninety-eight patients (88 males, 10 females, aged 38-91), diagnosed at Fundació Puigvert as having primary bladder cancer, were studied for L-myc restriction fragment length polymorphism (RFL); P 53 were superficial bladder tumours and 45 were invasive tumours. In addition, 110 normal DNA specimens from healthy blood donors (66 males, 44 females, aged 2-81) were analysed to investigate the genotype frequency of L-myc proto-oncogene.

High molecular weight DNA was isolated by standard phenol-chloroform methods. Restriction digests of DNA were performed with endonuclease Eco RI under standard conditions, electrophoresed in a $0.8 \%$ agarose gel, denaturated, transferred to Hybond ${ }^{\circledR}$ nylon membrane (Amersham) and hybridized with a ${ }^{32}$ P-labelled probe by the method essentially described by Southern (1975).

Received 4 June 1998

Revised 13 August 1998

Accepted 21 August 1998

Correspondence to: G Chéchile, Cartagena 340, 08025, Barcelona, Spain
All results obtained in these studies were analysed for statistical significance by the $\chi^{2}$ test with Yates' correction for adjustment when necessary. Differences between the two populations were judged significant at $P<0.05$. Kaplan-Meier curves were constructed to analyse patient survival between different genotypes (log-rank test).

\section{RESULTS}

Eco RI-digested DNA probed with the L-myc probe results in two fragments of $10 \mathrm{~kb}(\mathrm{~L})$ and $6.6 \mathrm{~kb}(\mathrm{~S})$, which are due to an Eco RI restriction site polymorphism (Figure 1). The distribution of the three genotypes (LL, LS, SS) in the control and patient groups is shown in Table 1. Chi-squared analysis showed that there was no difference between the distribution of the three genotypes of patient group and controls, and all are in accordance with Hardy-Weinberg equilibrium.

When the patients in the current study were examined for a relationship between the presence of S-alleles (LS or SS individuals) and distant metastasis, no association was found $(P=0.51)$. Nor was there a significant association between homozygosity for the

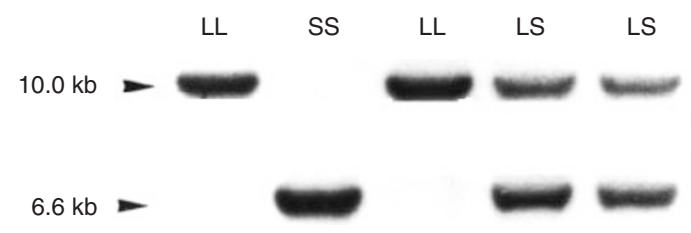

Figure 1 Examples of Southern hybridization analysis of the L-myc gene. DNA samples obtained from peripheral leucocytes of five control individuals are shown. Genotypes of lanes 1 and 3 were LL, that of lane 2 was LS, and those of lanes 4 and 5 were SS 
Table 1 Distribution of L-myc genotypes and allele frequencies in patients and normal controls

\begin{tabular}{|c|c|c|c|c|c|c|c|c|c|}
\hline & \multicolumn{4}{|c|}{ Genotypes } & \multirow[b]{2}{*}{$\chi^{2}$} & \multirow[b]{2}{*}{$(P)$} & \multicolumn{3}{|c|}{ Allele frequency } \\
\hline & $\overline{\mathrm{LL}}$ & LS & ss & $\overline{\text { Total }}$ & & & L & $s$ & $(P)$ \\
\hline Controls & 40 & 45 & 25 & 110 & & & 0.568 & 0.432 & \\
\hline Patients & 32 & 45 & 21 & 98 & 0.546 & $>0.05$ & 0.556 & 0.444 & $>0.05$ \\
\hline
\end{tabular}

Table 2 Data on patients with bladder cancer and the distribution of the L-myc genotypes

\begin{tabular}{|c|c|c|c|c|}
\hline \multirow[b]{2}{*}{ Total number } & \multirow[b]{2}{*}{ Total } & \multicolumn{3}{|c|}{ DNA pattern of L-myc no. of cases } \\
\hline & & LL & LS & ss \\
\hline \multicolumn{5}{|l|}{ Age (years) } \\
\hline$<60$ & 10 & 3 & 6 & 1 \\
\hline $61-70$ & 37 & 16 & 16 & 5 \\
\hline$>70$ & 51 & 14 & 26 & 11 \\
\hline \multicolumn{5}{|l|}{ Sex } \\
\hline Male & 88 & 28 & 44 & 16 \\
\hline Female & 10 & 4 & 1 & 5 \\
\hline \multicolumn{5}{|l|}{ Smoking } \\
\hline Yes & 71 & 23 & 34 & 14 \\
\hline No & 27 & 9 & 11 & 7 \\
\hline \multicolumn{5}{|l|}{ Grade of differentiation } \\
\hline $\mathrm{G} 1+\mathrm{G} 2$ & 45 & 14 & 19 & 12 \\
\hline G3 + anaplas. + indifferentiated & 53 & 18 & 26 & 9 \\
\hline \multicolumn{5}{|l|}{ TNM stages } \\
\hline $\mathrm{Ta}+\mathrm{T} 1$ & 53 & 18 & 25 & 10 \\
\hline $\mathrm{T} 2+\mathrm{T} 3+\mathrm{T} 4$ & 45 & 14 & 20 & 11 \\
\hline \multicolumn{5}{|l|}{ Recurrence $^{a}$} \\
\hline $\mathrm{R}+$ & 46 & 11 & 26 & 9 \\
\hline $\mathrm{R}-$ & 52 & 21 & 19 & 12 \\
\hline \multicolumn{5}{|l|}{ Distant metastasis ${ }^{b}$} \\
\hline $\mathrm{M}+$ & 28 & 7 & 15 & 6 \\
\hline M- & 68 & 25 & 29 & 14 \\
\hline \multicolumn{5}{|l|}{ Nodal metastasis ${ }^{c}$} \\
\hline $\mathrm{N}+$ & 15 & 4 & 9 & 2 \\
\hline $\mathrm{N}-$ & 71 & 26 & 30 & 15 \\
\hline \multicolumn{5}{|l|}{ Urethral involvement } \\
\hline$U+$ & 5 & - & 3 & 2 \\
\hline U- & 93 & 32 & 42 & 19 \\
\hline \multicolumn{5}{|l|}{ Prostate involvement ${ }^{d}$} \\
\hline$P+$ & 9 & 2 & 5 & 2 \\
\hline$P_{-}$ & 79 & 26 & 39 & 14 \\
\hline
\end{tabular}

aNumber of patients with previous relapses $(\mathrm{R}+)$ versus number of patients without previous relapses $(\mathrm{R}-)$. ${ }^{\mathrm{b} T h i s}$ variable was not possible to examine in two cases. ${ }^{~}$ This variable was not possible to examine in 12 cases. ${ }^{\mathrm{C}}$ Ten female patients were excluded of this examination.

S-allele and nodal metastasis $(P=0.46)$. Further analysis revealed no significant associations with grade of differentiation of tumours, TNM stages, number of previous and subsequent relapses, and urethral and prostate involvement (Table 2). No association was observed between L-myc RFLP and survival of bladder cancer patients (Figure 2).

\section{DISCUSSION}

An Eco RI polymorphism of the L-myc proto-oncogene was reported with the initial description of the gene (Nau et al, 1985) and the site of the polymorphism subsequently located in the second intron (Kaye et al, 1988). Studies of this polymorphism have linked it to both cancer susceptibility and prognosis. The role of L-myc in cancer susceptibility has been implied by studies showing differences in genotype frequencies between cancer patients and controls (Kato et al, 1990; Dolcetti et al, 1991; Crossen et al, 1994). The role of L-myc in prognosis has been suggested by studies showing that, among cancer patients, those that carry an Sallele (either LS or SS genotype) have earlier lymph node involvement or metastasis, or poorer survival than those who have genotype LL (Kakehi and Yoshida, 1989; Champeme et al, 1992; Kawashima et al, 1992). In contrast, Taylor et al (1993) reported a protective effect for the SS genotype in hepatocellular carcinoma. Hence, the association of the L-myc genotype with susceptibility and prognosis appears to vary with tumour type. 


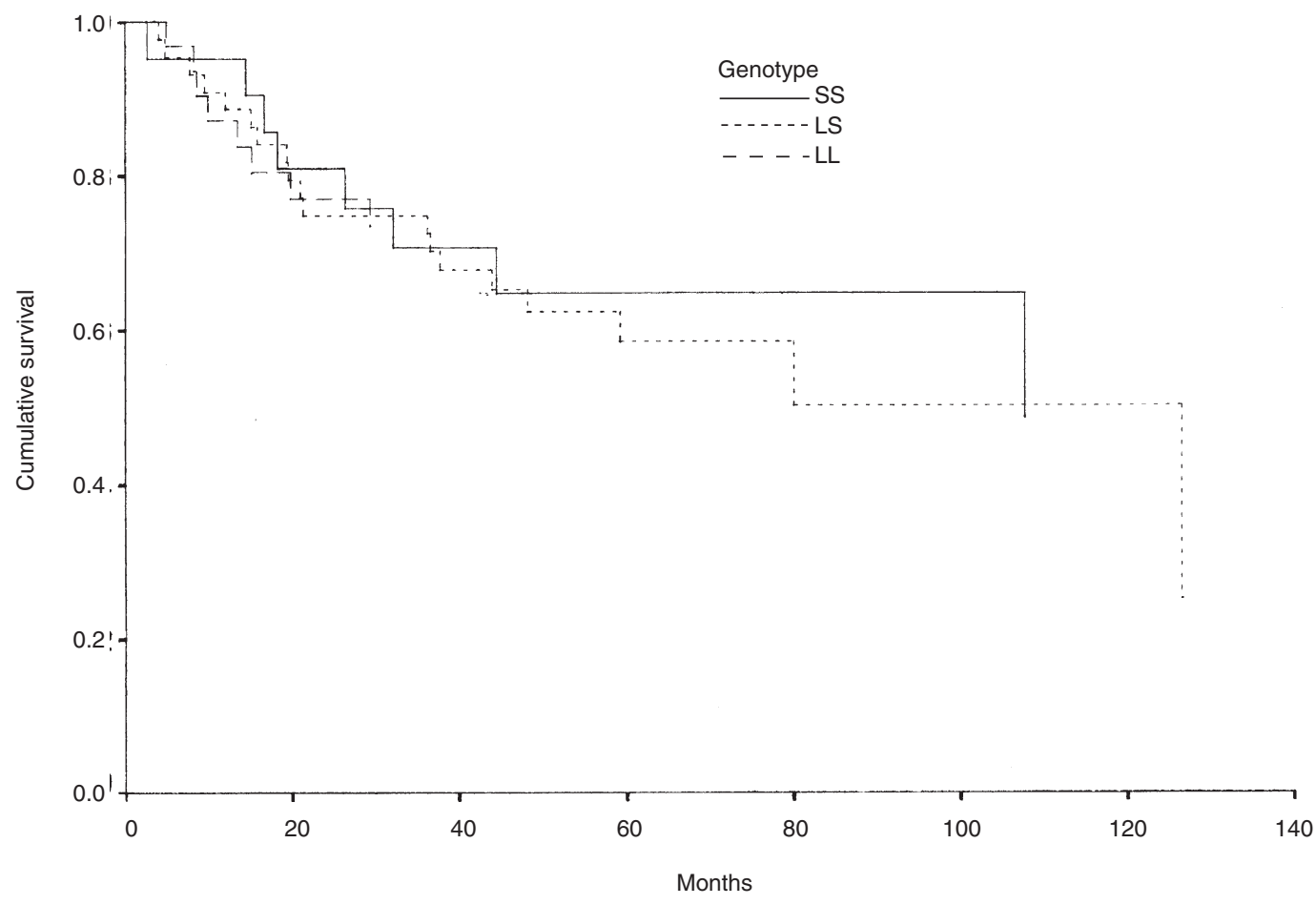

Figure 2 Survival curves of bladder cancer patients with LL, LS and SS L-myc RFLP (log-rank test, $P=0.53$ )

In this study, we examined the relationship between the L-myc RFLP pattern and the clinical features of bladder cancer in 98 cases. A preponderance of the LL, LS or SS fragments was not observed in the bladder cancer patients compared to normal healthy individuals; thus, presence of a particular allele did not indicate predisposition to bladder cancer. Similar L-myc allelic frequencies were also found in previously reported analyses.

Our results fail to support the hypothesis that the L-myc locus is involved in a genetic predisposition to bladder cancer. These results confirm those of Ikeda et al in colorectal cancer (1988), Tefre et al in lung cancer in Norway (1990), Ishizaki et al (1990) and Champeme et al (1992) in breast cancer, Saranath et al (1990) in oral cancer, Weston et al (1992) in lung cancer in the USA, Mironov et al (1994) in gastric cancer in Russia and Presti et al (1996) in renal cancer. On the other hand L-myc RFLP is correlated with the extent of metastasis of lung cancer in Japan (Kawashima et al, 1988, 1992) and in renal cancer (Kakehi and Yoshida, 1989); Ishizaki et al (1990) also reported that the presence of the S-allele is associated with poor prognosis due to metastasic lesion in gastric cancer. Kato et al (1990) proposed that Japanese men with the S-allele may be prone to development of osteosarcoma and Saranath et al (1990) observed that patients with oral cancer with a genotype including an S fragment are more likely to develop a poorly to moderately differentiated tumour, or a larger tumour, than patients without an $\mathrm{S}$ fragment.

Our results show that the L-myc genotype does not correlate with tumour grade or stage in patients with bladder carcinoma. No significant correlation was observed between the L-myc genotype and the presence of nodal metastases or distant metastases at the time of surgery or with subsequent disease relapse.
This study did not demonstrate an association between the L-myc genotype and disease status in bladder cancer. It seems that L-myc polymorphism is not suitable as a prognostic and susceptibility marker in the bladder cancer patients studied.

\section{ACKNOWLEDGEMENTS}

This work was partially suported by a grant from Ministerio de Educación y Ciencia (DGICT PM 910123). We thank Japanese Research Bank for the L-myc probe.

\section{REFERENCES}

Champeme MH, Bieche Y, Latil A, Hacene K and Liderau R (1992) Association between restriction fragment length polymorphism of the L-myc gene and lung metastasis in human breast cancer. Int J Cancer 50: 6-9

Crossen PE, Morrison MJ and Colls BM (1994) Increased frequency of the S allele of the L-myc oncogene in non-Hodgkin's lymphoma. Br J Cancer 69: 759-761

Dolcetti R, Pelucchi S, Maestro R, Rizzo S, Pastore A and Boiocchi M (1991) Protooncogene allelic variations in human squamous cell carcinomas of the larynx. Eur Arch Otorhinolaryngol 248: 279-285

Ikeda Y, Ishizaka Y, Ochiai M, Sakai R, Itabashi M, Honda M, Sugimura T and Nagao M (1988) No correlation between L-myc restriction fragment length polymorphism and malignancy of human colorectal cancers. Jpn J Cancer Res (Gann) 79: 674-676

Ishizaki K, Kato M, Ikenaga M, Honda K, Ozawa K and Toguchida J (1990) Correlation of L-myc genotypes to metastasis of gastric and breast cancer. Natl Cancer Inst 82: 238-239

Kakehi Y and Yoshida O (1989) Restriction fragment length polymorphism of the L-myc gene and susceptibility to metastasis in renal cancer patients. Int $J$ Cancer 43: 391-394

Kato M, Toguchida J, Honda K, Sasaki MS, Ikenaga M, Sugimoto M, Yamaguchi T, Kotoura Y, Yamamuro T and Ishizaki K (1990) Elevated frequency of a 
specific allele of the L-myc gene in male patients with bone and soft-tissue sarcomas. Int J Cancer 45: 47-49

Kawashima A, Shikama H, Imoto K, Izawa M, Naruke T, Okabayashi E and Nishimura S (1988) Close correlation between restriction fragment length polymorphism of the L-myc gene and metastasis of human lung cancer to the lymph nodes and others organs. Proc Natl Acad Sci USA 85: 2353-2356

Kawashima K, Nomura S, Hirai H, Fukushi S, Karube T, Takeuchi K, Naruke T and Nishimura S (1992) Correlation of L-myc RFLP with metastasis, prognosis and multiple cancer in lung-cancer patients. Int J Cancer 50: 557-561

Kaye F, Battey J, Nau M, Brooks B, Seifter E, DeGreve J, Birrer M, Sausville E and Minna J (1988) Structure and expression of the human L-myc gene reveal a complex pattern of alternative mRNA processing. Mol Cell Biol 8: 186-195

Mironov NM, Aguelon AM, Potapova GI, Gorbunov OV, Klimenkov AA and Yamasaki H (1994) L-myc allele polymorphism and prognosis for metastases in Russian gastric cancer patients. Eur J Cancer 30: 1732

Nau MM, Brooks BJ, Battey J, Sausville E, Gazdar AF, Kirsch IR, McBride OW, Bertness V, Hollis GF and Minna JD (1985) L-myc, a new myc-related gene amplified and expressed in human small lung cancer. Nature 318: 69-73
Presti JC Jr, Hinckley J and Reuter VE (1996) L-myc allelotype in renal cell carcinoma. Cancer Genet Cytogenet 88: 66-68

Saranath D, Panchal RG, Nair R, Metha AR, Sanghavi V and Deo MG (1990) Restriction fragment length polymorphism of the L-myc gene in oral cancer patients. Br J Cancer 61: 530-533

Southern EM (1975) Detection of specific sequences among DNA fragments separated by gel electrophoresis. J Mol Biol 98: 503-517

Taylor JA, Bell DA and Nagorney D (1993) L-myc proto-oncogene alleles and susceptibility to hepatocellular carcinoma. Int J Cancer 54: 927-930

Tefre T, Borresen AL, Aamdal S and Brogger A (1990) Studies of the L-myc DNA polymorphism and relation to metastasis in Norwegian lung cancer patients. Br J Cancer 61: 809-812

Weston A, Caporaso EN, Perrin LS, Sugimura H, Tamai S, Krontiris TG, Trump BF, Hoover RN and Harris CC (1992) Relationship of H-ras-1, L-myc and p53 polymorphisms with lung cancer risk and prognosis. Environ Health Perspect 98: $61-67$ 